\title{
(Un)making Canberra: Craft and the designing of settler-colonialism in Australia
}

\author{
Matthew Norman Kiem
}

\begin{abstract}
This paper examines how practices of craft and design are involved in making and unmaking worlds. Specifically, it draws attention to the role of craft and design within settler-colonialism, understood as a structural condition in which a colonising force seeks to appropriate land from indigenous inhabitants. While the topic of settler-colonialism implicates questions concerning sovereignty, biopolitics, and coloniality, this paper demonstrates how these issues can be studied as both designed and designing effects. This is done through an analysis of the colonial history of Canberra, Australia's capital city and home of its federal parliament. Following an account of how the traditional world of the original indigenous inhabitants was displaced through the material and symbolic interventions of early settlers, this paper argues that the first design proposals for the city bear out key characteristics of the relationship between craft, design and colonialism.
\end{abstract}

The whole of Australia is an Aboriginal artefact.

(Bayet-Charlton 2003: 174)

Craft is an empire.

(Greenhalgh 1997: 21)

\section{Introduction: History against the (un)making of colonial defuturing}

Using Canberra, the federal capital of Australia as a case study, the broader intention of this paper is to present a critical counterposition to those discourses and practices that sustain the 'durabilities of duress' that persist within a settler-colonial context such as Australia (Stoler 2008: 192). As Ann Stoler has argued, virtually all colonies, and as I would argue here, all settlercolonial societies, 'are artefacts of deliberate and concerted design'; that is, conscious material interventions in the 'subjunctive mood' whose shifting impact over time conditions the socio-political topology of domination and resistance (Stoler 2011). In doing so, this paper presents a rudimentary sketch of relations between histories, futures, craft and design, and coloniality. It is worth acknowledging that my experience of writing this paper - a task which marks the beginning of a longer term project - has been one of way finding within an inchoate theoretical territory. This is not to suggest that there is no literature that bears on the relations I am trying to articulate, but such material 
is almost exclusively produced in other disciplines. As a consequence, the historical agency of craft and design tends to be disclosed in diffuse, indirect or unintended ways. Work that directly problematises the role of craft and design vis-à-vis enduring conditions of colonial domination is scarce.

That said, there has been recent work done in the history of planning, architecture and housing that provides a valuable point of departure for this paper (Banivanua-Mar \& Edmonds 2010; Pieris 2009; Veracini 2012), some of which also examines the spatial politics of Canberra (McGaw, Pieris \& Potter 2011; Pieris 2012). Much of this work either emerges from or draws upon the critical framework of settler-colonial studies (Bateman \& Pilkington 2011; Veracini 2010; Wolfe 2006), a strategy that is continued in this paper. To this I bring a perspective developed in my work with Tony Fry's concept of defuturing, a term that names both the designed autodestruction of futures and a mode of reading that looks to disclose its agency (Fry 1999). The result is an analysis positing colonial violence as a designed effect that continues to design, rather than as a bounded event or period of the past.

More specifically, my aim here is to demonstrate that there are consequences of the kind of histories we produce that are reflected in, and amplified by, acts of making. ${ }^{1}$ This point is not meant to imply that making simply receives, in a passive way, the authoritative interpretations of historians. Rather, as the philosophical thinking of Martin Heidegger suggests, making is an active part of our beinghistorical (1962; 2008). This point speaks to the hermeneutical structure of making, a phenomenon cogently described by Anne-Marie Willis as 'ontological designing' (Willis 2007). ${ }^{2}$ In short, ontological designing acknowledges that the understanding that allows making to happen, an understanding that always includes an historically conditioned sense of its own temporality, tradition and direction, is itself changed by what is made. Clocks and war memorials, for instance, are each, in their own ways, both products and mediums of the temporal rhythms of imagined communities (Anderson 1991; Davison 1993). 'The made', understood here as the combined effect of 'the designed' and 'the crafted', is, therefore, the condition in which histories are written, just as the historical understanding reflected in written histories conditions what is made.

1 In a work that parallels the interests of this paper in various ways, Paul Carter has characterised imperial history - a term he applies not to writers of a past 'imperial era', but to more contemporary historians such as Manning Clark and Geoffrey Blainey - as a 'defensive appeal to the logic of cause and effect' that 'demonstrates the emergence of order from chaos' (Carter 2010: xvi). As Carter's argument intimates, the meaning of 'order' and 'chaos' is always perspectival, that is, dependent upon whether you are, say, the coloniser, the colonised, or the historian who disciplines the contingencies of events into a coherent narrative. Again, the chaos caused when one 'worldview' (often obliviously) dominates an Other, is a violence that continues to play out today. For a current Australian example, see Tess Lea's account of the bureau-professional anarchy of the Northern Territory 'Intervention' (Lea 2012).

2 The significance of ontological designing has been most extensively demonstrated in the work of Tony Fry $(2009,2011,2012)$. A theoretically similar approach was used by Terry Winograd and Fernando Flores' in Understanding Computers and Cognition (1987). 
The issues at stake here - including what, how, or why we make; our understanding of what designs a city and what a city designs; and how we, as historical agents living in the present, engage with what consequences past actions have determined for 'us' and 'our' futures - are all questions that are either confronted or obscured by the histories we choose to write. In this sense, the politics of this paper is based on the idea that historical enquiry is always a more or less futural (re)interpretation of our historical understanding, in that it either aids or hinders a confrontation with defuturing, rather than ever being an 'objective' account of the past (Fry 1999: 60-63).

Therefore, against any interest in celebrating Canberra as an achievement - architectural, cultural, national or otherwise - this paper proposes that Canberra should be read as a designed instrument of, and for, the ethnocidal destruction of indigenous people (Clastres 1988), and the biopolitical production of compliant subjects (Foucault 2007; 2008). While what follows can only be a single and provisional sketch of a much larger project - design towards decolonial sustainment - it is nevertheless grounded in an explicit cultural politics, one that argues that histories either annihilate futures by legitimating the defutural present, or challenge us to mount a serious response to the designed durability of duress.

\section{Dwelling as (un)making worldhood}

Craft and design are world-making practices. As Fry (1994) and Willis (2007) have argued, both craft and design are essential to being-in-the-world - the term coined by Heidegger to describe the ontological structure of 'our' existence (Heidegger 1962: 78-90). This 'being-in' names something that is different from either a physical or abstract sense of location, such as being 'in the house' or 'here on the map'. These descriptions are too Cartesian, too caught up in discrete notions of cogito and extension that conceptually distinguish 'me', as a thinking subjectivity, from the 'objective' world 'outside'. Being-in-the-world, on the other hand, acknowledges that we never encounter ourselves as a discrete subject, that we are essentially a being whose existence is its worldhood. In other words, we are a being who always finds itself thrown amidst a meaningful context of equipment, people, and practical choices that matter to us. As the later Heidegger would describe it, being-in-the-world has something more to do with dwelling; with having a body, temporality, language, and skills; with being on the earth, under the sky, amongst other mortals, and in the presence of the gods (Heidegger 2008). Following Heidegger, this paper takes up the idea of dwelling (by craft and design) as a precondition for building (by craft and design). 
The ethics of world-making, however, is never a given, due to the fact that craft and design are always equally involved in world-unmaking. ${ }^{3}$ It is through these practices that weapons are produced, plans are laid, and campaigns that entail the destruction of people and cultures are waged. At one level this dialectic between destruction and creativity is unavoidable and necessary (Fry 2004). Making something always requires the destruction of something else. Destruction is, therefore, the basis upon which all making is possible, and the only means we have of sustaining ourselves. The world-making of Western, ethnocidal modernity, however, has come to represent a way of being that radically departs from the principle of only creating things that are more important than whatever is destroyed in the process. Rather, modernity has come to represent a way of being that progressively destroys the ability to sustain anything at all (Fry 1999).

\section{Knowledge, power, and the colonial academy}

In 1995, Murri scholar Philip Morrissey wrote a briefing essay for a craft exhibition. In what he describes as a pessimistic but strategic piece, Morrissey provides a poignant reaction to the politics of colonialism:

The invasion of Australia: I realise something is happening when I read these words again, offered without qualification, in another post-Colonial essay. An intellectual - two steps ahead of the community - at least in the area of naming. Australia wasn't settled - it was invaded. 'Not by me' is the epistemological ground of this statement - part of an enlightened academic rhetoric which intersects with ressentiment Aboriginal politics (a querulous politics, predictable and conformist which serves a liberal status quo) and Federal government race discourse. The underlying supposition being that White Australia will change when educated (or taunted with evidence of its racism) enough. (Morrissey 1995)

For academics seeking to engage with the question of Australia's coloniality, this quote, in part, articulates the power/knowledge problematic described by Michel Foucault (1980). In simple terms, because a claim to knowledge constitutes an imbalance between those who are 'in the know' against those who are not, the conditions under which knowledge is produced, stolen, legitimated, shared, imposed, received, and deployed, is always constituted by relations of power. Morrissey highlights this precise point when he describes his dissatisfaction with the socio-political effect (not the factuality) of (white) intellectual politics, namely, the self-absolution of gestural challenges.

In Australia, this relation between knowledge and power has an acute and tangible edge. As a non-Aboriginal or a Torres Strait Islander person, I am four times more likely to have a bachelor degree and 14 times more likely not to have been imprisoned (Australian Bureau of Statistics 2010; 2012). The asymmetry

3 As a key concept in this paper, the inseparable relation making and unmaking is given dual presence through the term '(un)making'. Precedents for thinking making in these terms can be found in the work of Fry (1999: 22, 277) and Tony Birch (2003). 
that determines whose knowledge is more likely to be used against whom is stark, and has been since ever since European settlement began. Over this period, the academy has been implicated in scientific efforts at 'dealing with' Aboriginality, that 'excluded inclusion' which persists as a residual problem for (and consequence of) settler-coloniality (Wolfe 1997: 59-60). In this light, it is worth noting that my own ability to write and publish this paper is predicated on privileges conferred by an institution whose historical raison d'être is indivisible from the project of colonisation. ${ }^{4}$

Nevertheless, this paper is written with presumption that a decolonial design history not only is possible, but, in a settler-colonial context such as Australia, it is a necessary part of understanding the devastation that endures, not only for indigenous peoples, but all socially-marginalised groups, including refugees. ${ }^{5}$ With this in mind, and following Patrick Wolfe's warning to 'reluctant invaders', the objective of this enquiry is a politicised understanding of Canberra's design(ing), not another way of knowing (as power over) indigeneity (Wolfe 1992).

\section{The biopolitical designing of settler-colonial sovereignty}

The term 'settler-colonialism' distinguishes those societies - such as Australia, New Zealand, North America and Israel - that are built and maintained through processes of displacing pre-existing indigenous people (Wolfe 2006). David Day has proposed the similar concept of 'supplanting societies' in reference to the way in which a colonising force deploys a variety of techniques across different fields of activity to achieve, maintain, and naturalise its territorial dominance (Day 1998: 6). The integration of a territory into the invaders' economic, juridical, and cultural world - which could also be thought of as their way of integrating themselves into the land - reflects a desire to suppress any competing claim to the territory, including any anterior form of economic, legal, or other cultural practices that link the previous culture to the land. Thus the prevailing logic of the invading force becomes the ethnocidal elimination of the native (Wolfe 2006).

Day's argument suggests that supplanting is a devastating, but otherwise normal and repetitive occurrence throughout human history. Following Walter Mignolo,

4 'Academic knowledge about Aboriginal knowledge can never be innocent. It is too deeply enmeshed in a historical relationship through which one's power is the other's disempowerment. From the outset, authoritative pronouncements on Aboriginal mentalities have been central to the invasion and expropriation of Koori people - terra nullius was, after all, a discourse on rationality.' (Wolfe 1997: 83). See also Linda Tuhiwai Smith's Decolonizing Methodologies: Research and indigenous peoples (1999).

5 Given the upheavals expected to flow from the consequences of climate change, it is fair to expect, in the short term at least, that these conditions will get worse well before there is any improvement. It is not inconceivable, for instance, that Australia will one day face its own internal refugee crisis. Even more troubling, however, is the recognition that a politics that can humanely address these prospects does not yet exist (Agamben 2001). For more on the concept of design futuring and its relation to decolonial knowledge see Tony Fry's Design Futuring (2009), particularly chapters 6 and 7. 
however, I believe it is reasonable to view the colonisation of the Australian continent as one part of a unique historical phenomenon, namely, the globalisation of Western power. While Western dominance has waxed and waned at certain times and in various places, globalised colonialism continues to sustain itself through what Mignolo terms the 'colonial matrix of power': the interrelated domains of economy (capitalism); authority; race, gender and sexuality; and knowledge and subjectivity (Mignolo 2011: 1-24).

Together, the work of Mignolo and Wolfe characterise colonialism as a form of active structuring by means of a variety of state-mediated, biopolitical (governance of life) regimes (Morgensen 2011; Wolfe 2006: 388). Importantly, as Foucault argued, this power is as much a productive, or for our purposes, a designing force, than anything simplistically restrictive or repressive (Foucault 2003: 2008). As such, while 'elimination' does indeed involve cases of killing from frontier wars to deaths in custody - it also operates through the ontological designing of lives that are amenable to the logic of settler-colonialism. The elimination of the native, therefore, is not simply matter of eliminating a certain kind of biological life. Rather, settler-colonialism is just as interested in the creation of healthy, compliant populations, as it is in the destruction of any cultural life that challenges its sovereignty. ${ }^{6}$

The ontological designing of settler-colonial sovereignty can, therefore, be characterised as not only distinct from, but also structurally hostile to Aboriginal sovereignty (Graham 1999; Moreton-Robinson 2007). Aileen Moreton-Robinson, for instance, argues that whereas Western constructs of sovereignty are based on 'the social contract model, the idea of a unified supreme authority, territorial integrity and individual rights',

Our [Aboriginal] sovereignty is embodied, it is ontological (our being) and epistemological (our way of knowing), and it is grounded within complex relations derived from the intersubstantiation of ancestral beings, humans, and land. (Moreton-Robinson 2007: 2)

As Moreton-Robinson and others have argued, the effect of sovereignty is not (just) a juridical matter (Moreton-Robinson 2007). Because it is concerned with how the political body is constituted (as individual and as polity), sovereign power works to exert a shaping (designing) effect upon the socio-material conditions of space, ownership, education, home-making, and the representation of nationalhistorical mythologies. As the symbolic home of settler sovereignty, the city of Canberra represents both a unique and representative case of settler-colonial designing at work.

6 From this paragraph onwards, Foucault's account of biopolitics has been simplified in the way that it blends what are otherwise important distinctions between sovereign, discipline, and security techniques of power. To correct this economical misrepresentation see Foucault's Discipline and Punish (1991) and Security, Territory, Population (2007). For a wider reading of Western sovereignty see Alain de Benoist's 'What is sovereignty?' (1999), Georgio Agamben's Homo Sacer (1998), and Tony Fry's Design as Politics (2011). For more on Aboriginal sovereignty see Aileen MoretonRobinson's (ed.) Sovereignty Subjects (2007). 


\section{From Ngambri to Canberra}

The city of Canberra is built on land that was a site of world-making long before the arrival of Europeans. When Europeans began colonising the district in the 1820s, they interrupted the world of the Ngambri, a people who embodied a mode of dwelling that had sustained them and their ancestors for tens of thousands of years. The 1820s Ngambri were a distinct group with their own language and complex relationships with neighboring groups. My account of this history relies mostly on Anne Jackson-Nakano's (2001) study of the Ngambri experience of colonial settlement, ${ }^{7}$ as well as relevant sections of Bill Gammage's (2011) thesis on Indigenous land use.

The colonial record suggests that the pre-invasion Ngambri used sophisticated fire techniques to shape the landscape to their advantage (Gammage 2011: 275-80) and there are still trees today that bear the marks of bark harvesting for canoe construction. Settler accounts of Ngambri ceremonies and trials indicate autonomous practices of law and social regulation, revealing that, like any other culture, the Ngambri mode of dwelling involved practices of making that were embedded in a complex socio-material ecology that integrated land and artefacts into law, kinship, and traditional story telling. The first sheep stations, which were built on nearby ridges, overlooked 'grass-forest templates, springs, swamps, fords, camps, and ceremonial grounds' that were both the work and the world of Ngambri. Considering the time and care embodied in both land and people, as well as the ignorance of the colonisers, in both senses of the phrase, the first white station masters 'overlooked the work of generations' (Gammage 2011: 280). These initial constructions of the grazier's gaze signal the first moves towards Eurocentric world-(un)making in Ngambri country.

While relations between individual Europeans and Ngambri were complex at times brutal, at others benevolent, even friendly - the course of events followed the colonial logic of elimination. This trajectory was set decades earlier when, in 1770, Captain Cook laid claim to the eastern part of the continent in the name of the British Crown. At that point, Ngambri country became a de jure part of the British empire - even though it was unknown to Europeans other than as a 'theoretically there' indication on a map. The de facto claiming began years later, with the creation of the first sheep runs, and official acts of surveying and mapping (see Figure 1). These acts were part of a cultural process of repossession, whereby the territory was literally (un)made into something that was available to colonial administration and exploitation by capital. Mapping, for instance, allowed for the parcelling of land under the peculiarly individualist, and productivist regime of European property law. The ontological designing of this process has been described by Willis (2012):

what's going on is induction into a particular way of knowing and being in the world - one that, as it gathers momentum, becomes 'indispensible',

7 That Jackson-Nakano titled her book The Kamberri is some indication of how the recovery of Ngambri culture, language, and identity is still a work in progress. 
displacing other ways of knowing and being in the world. ... The traditional survey map conceals time. It plots out locations in space, as if time is of no consequence; as if what it describes always existed and will always exist. Yet, as argued, spaces are mapped as a precursor to change, thus maps were (are) catalysts for ending the time of one thing and inaugurating the time of what is to come.

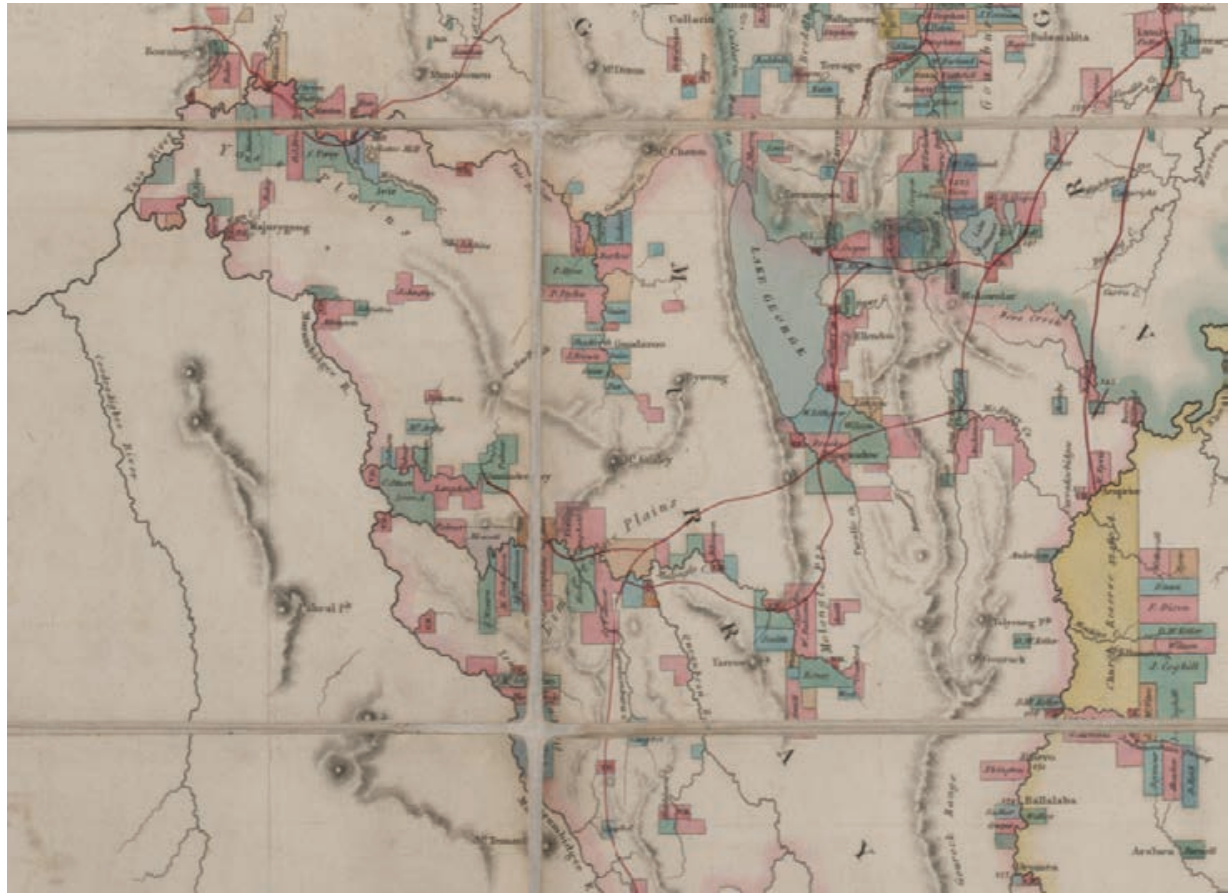

Figure 1. Section of a 1837 map of the Colony of New South Wales 'Exhibiting the Situation and Extent of Appropriated Lands' southwest of Weereewaa (Lake George), designed by Surveyor Robert Dixon and engraved by J. \& C. Walker. Published in London, this map served to indicate the availability of land to prospective immigrants (Brock 2006: 7).

Source: National Library of Australia, http://nla.gov.au/nla.map-rm831, viewed 4 Oct. 2012

In the face of this destructive momentum of colonial (un)making, the response of many Ngambri was to retreat into nearby mountains. Local camps were maintained and, during the period of 1830 to 1845, various Ngambri became increasingly familiar with the white settlers. Bartering over goods and services started between the two cultures and some Ngambri began working for the white settlers. This was also the period in which Europeans distributed blankets and clothing to Indigenous groups - an act of charity that helped to 'domesticate' a potential labour force, and provided an opportunity to record and monitor populations.

Increasingly dispossessed of their traditional means of sustainment, some Ngambri joined other groups on a circuit between the Christian missions and state reserves that were established in and around the region. This movement 
was halted in the 1890s, when officials decided that Indigenous peoples must be made to settle down. While the missions and reserves kept many alive, they also functioned as a means of culturally destroying Aboriginality. The bureaucratic designing of Aboriginality was facilitated by the scientific discourse of miscegenation, with white officials taking it upon themselves to decide at what point a person of 'mixed blood' was no longer Aboriginal. To be designated 'half-caste' signaled that one was an 'able-bodied' European who ought to be removed from the company of 'pure' Aboriginals and integrated into the settler labour force.

As the population of settlers increased, so did white border anxiety about camps set up by Indigenous people on the fringes of towns. Indigenous groups took to dividing their numbers across the area, a tactic that would have helped to quell white retaliation, but may also have contributed to the popularity of the extinction myth. This reached its zenith in 1897, with the death of elder Nellie Hamilton. Hamilton's passing prompted declarations that the 'Queanbeyan tribe' - an imposed title - was no more. While Ngambri descendants continued to live and work in the area, they were not considered 'Aboriginal' enough to challenge settler conceptions of Aboriginal demise.

While the damage to the culture at this point was extensive, contemporary Ngambri are able to trace their ancestral connections through the written record. Of the few Ngambri voices that survived this period, Hamilton's response to a white man's claim that 'our law punishes thieves' provides a rare sense of the Ngambri experience of pre-Federation colonialism:

Your law! I no tink much of your law. You come here and take my land, kill my 'possum, my kangaroo; leave me starve. Only gib me rotten blanket. Me take calf or sheep, you been shot me, or put me in jail. You bring bad sickness 'mong us. (Gale 1977: 123)

In 1911, the recently established Commonwealth took possession of the Australian Capital Territory after the land was formally surrendered by the New South Wales Government. On 12 March 1913, an outdoor ceremony was held to name 'Canberra' - an anglophone derivation of 'Ngambri' - as the site for the new capital city. The Ngambri of course had no say in either the transfer of ownership or the use of the name. Far from being an act of respect, the appropriation of 'Canberra' into a European tradition of place naming represented a further means of naturalising colonial dominance. ${ }^{8}$ As Tony Birch has described it, this was yet another example of how Europeans "make" and "unmake" Indigenous people' (2003: 153).

8 'Attaching names to landscapes legitimises the ownership of the culturally dominant group that 'owns' the names. Indigenous names themselves do not constitute a threat to white Australia. Houses, streets, suburbs and whole cities have Indigenous names. This is an exercise in cultural appropriation, which represents imperial possession and the quaintness of the 'native'. For colonisers to attach a 'native' name to a place does not represent or recognise an Indigenous history, and therefore possible Indigenous ownership.' (Birch 2003: 150) 


\section{Crafting the modern-colonial capital}

The building of Canberra was delimited by its historical conditions. Its formation was always going to reflect an imposed version of Western sovereignty and its regimes of biopolitical governance. The particulars were to be influenced by the dominant planning theories of the Western world at the time, namely the City Beautiful and Garden City movements (Vernon 2006). The way in which craft and design played a role in materialising Australian settler-colonialism is, however, significant. This section examines how craft and design progressed the modernist-colonial agenda by focusing on the ontological designing of the city plan produced by Marion Mahony Griffin and Walter Burley Griffin. While this analysis leaves out what has occurred since this time, it does provide a sense for how the construction of Canberra, as place and image, has always implied the ongoing structuring of settler-colonialism.

In April 1911 the competition for the design of Canberra was announced. The brief stipulated that 'the Federal Capital should be a beautiful city, occupying a commanding position' and submitted designs should embody 'all recent development in the science of town planning' (Department of Home Affairs 1911: 6). Packages were assembled that included a variety of maps, and two panoramic paintings of the landscape. Housed in wooden boxes, these packages, along with a topographic model of the site, were sent to locations across Australia, New Zealand, South Africa, Europe, and North America. Given the technology at the time, these artefacts would have been produced through various processes of drafting, painting, printing, and modelling. The total effect was a crafted mediation of Ngambri country that rendered the land as a radically different kind of object - a blank canvas for the gods-eye-view of the white, urban designer. $^{9}$

In May 1912, Chicago architect Walter Burley Griffin was declared the winner of the competition, although his success had much to do with the contribution of his wife, Marion Mahony Griffin, as well as a team of assistants. Beyond helping with the design, Marion directed the process of rendering the perspective drawings (Figure 2). The production of these drawings was a complex exercise, which not only required its own planning, but, also, the deft touch of a skilled hand:

[Marion Mahony Griffin] was making drawings on the silky Japanese vellum with a crow quill pen and brown ink. The hairy surface would catch the pen unless it barely skimmed the surface, in which case BLOT and finish for that sheet - start all over again. (Reid 2002: 45)

9 'The architect's procedures of coding and decoding through drawing seem to be transparent but in reality act as filters, eliminating some aspect of the site as they invent others.' (Duggan 2009: 87) 


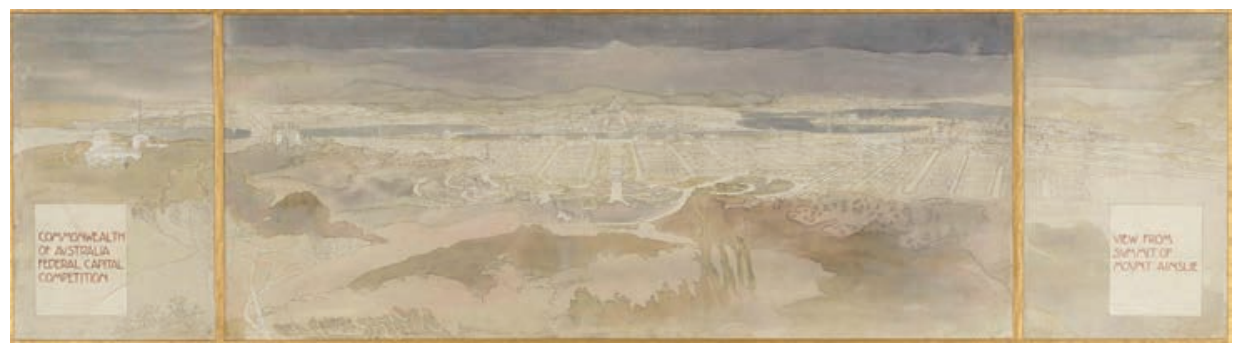

Figure 2. 'View from the summit of Mount Ainslie', a perspective drawing of the Griffins' 1912 design for Canberra, rendered by Marion Mahony Griffin.

Source: http://en.wikipedia.org/wiki/File:Canberra_plan_view-WBG.jpg, viewed 4 Oct. 2012

In the context of what the Griffins' were trying to achieve, this account demonstrates how craft skill was deployed as a force of modernity - in this case, as an evocative communication of an imaginary space. The ontological designing of this work, as it expresses and shapes the worldhood of the (un) maker, has been eloquently described by Laurie Duggan:

For the builder of 'model cities', like the more modest builder of model ships, indulges a nostalgic desire to control every aspect of production; a desire (in the model ship builder's case) to exercise 'craft' rather than simply to perform, as alienated labourer, a task on a production line. This nostalgia may (in the architect's case) result in an attempt to recover the imagined city of a previous era or, at least, produce a 'modern' (or modernist) city - even a 'city of the future' - from a set of unexamined concepts which will, in practice, bind a society even more tightly to the real or imaginary past. (Duggan 2009: 87)

The beauty of the artefacts produced by the Griffins, however, belies its conformity with an ethnocidal biopolitics. In his explanation of the proposal, Walter Burley Griffin outlined how each domain of modern life was provided for within his plan. Beyond physically separating the functions of government (given a position of visual and moral authority), civil society, and marketplace, Walter also described how, and to what end, the city would produce a modern domestic subject:

[T] he segregated sections ... comprise social units for ... the neighbourhood group, with one handy local district school ... local playground, game fields, church, club, and social amenities accessible without ... encountering the disturbing elements or temptations of business streets, since these family activities may best be directed internally toward the geographical centres of their groups ... In other words, the adult and independent industrial social activities may be considered typically directed centrifugally, whilst the domestic social efforts are assembled centripetally for effective control and co-operation. (Department of Home Affairs 1913: 13)

While Walter imagined the domestic sphere as a place free from the 'interference or encroachment of business life', its role was still, primarily, to produce a 
healthy and disciplined labour force that was 'everywhere handy to industrial employment' (Department of Home Affairs 1913: 12) (for more on the relation between suburban forms and settler-colonialism see Veracini 2012).

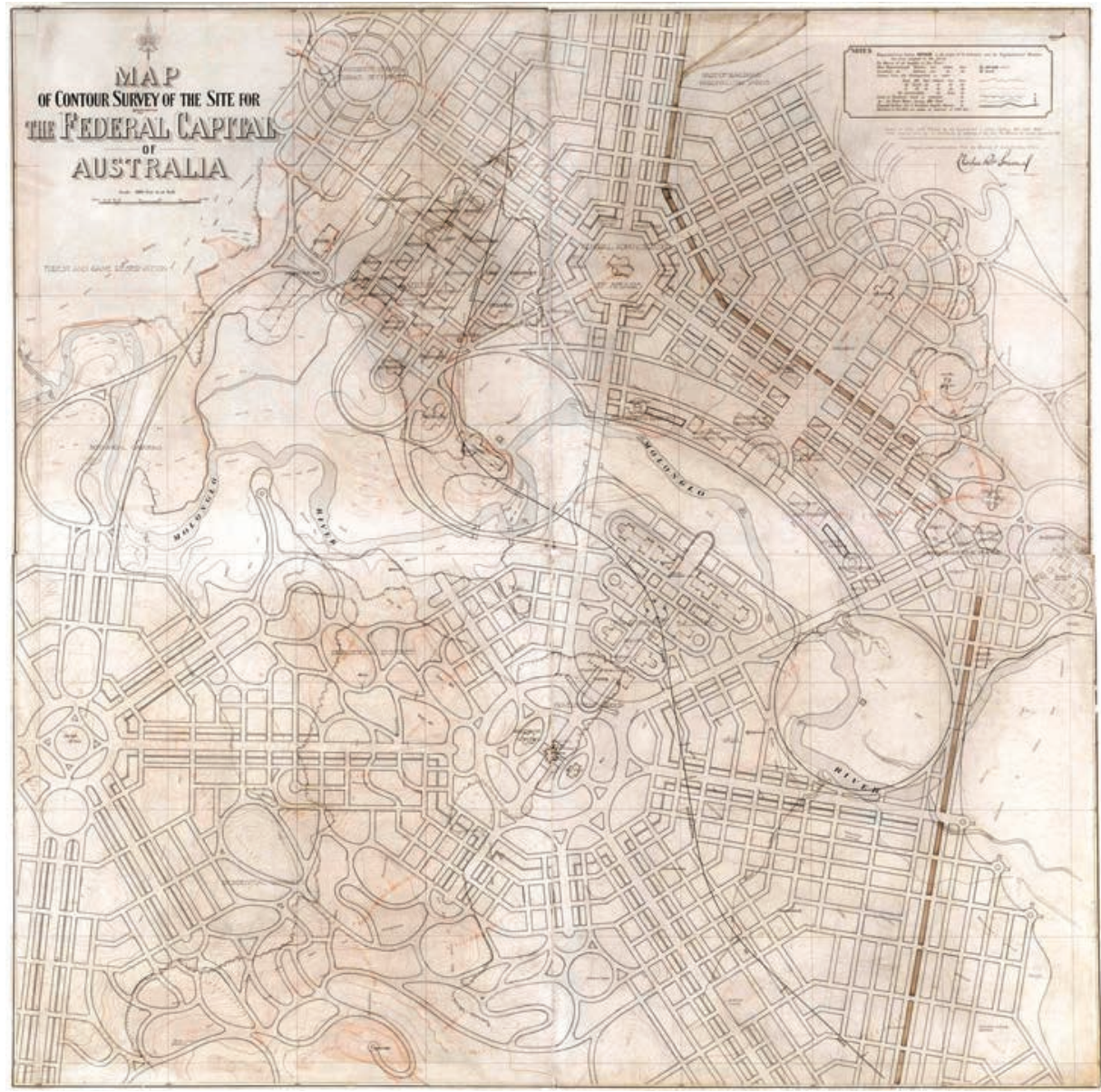

Figure 3: A map of the Griffins' 1912 design for the city of Canberra overlaying the topographic map supplied in the competition package.

Source: http://en.wikipedia.org/wiki/File:Canberra_plan-WBG.jpg, accessed 4 Oct. 2012

The Griffins' design is often lauded for how it integrated the city into the landscape. Historians celebrate, for instance, the way in which 'the natural world is not something to be altered to fit the design, but the design is a response to the particular place it is in' (Vernon 2002: 19). Such romantic rhetoric, however, works to obscure the enduring violence of colonial place-(un) making. Specifically, it fails to acknowledge that 'nature', 1) is not natural, but, rather, a cultural concept that is materially, visually, and rhetorically constructed within socio-material relations; 2) it is a designed imaginary that designs; and 
3) in Australia, the ability of settlers to picture 'nature' as an aesthetic object is necessarily premised on the destruction of Indigenous worldhood, people, and place.

Paul Carter's study of early settler place-(un)making provides support for these three points. Before settlers' could write, paint, or talk about 'nature' as a picture of serenity - rather than something 'wild' and threatening - the work of clearing and enclosure, symbolic and physical, had to occur. ${ }^{10}$ This (un) making established the necessary (in)security ${ }^{11}$ of place from which a romantic 'outlook' could develop. Within these spaces, home-(un)making could unfold as a 'proliferation of symbolic boundaries' that were defined and policed through further acts of (un)making. A good example is the case of furniture that was said to look " "nice and comfortable" ... because the wilderness of the wood has been tamed, covered in cretonne' (Carter 2010: 153-54). Regarding one settler's recollection of an early morning landscape, Carter comments that, 'the pleasure she takes in the view depends on trespassing there: for home does not shut out the forest, but transforms it into a cultural object, a wilderness into a kind of beauty' (2010: 155).

If we take Carter's point regarding the construction of wilderness as a cultural artefact from the context of the settler home and extend it to that of an entire city, the ideological function of the notion that the Griffins' design did not alter the 'natural world' becomes clear. By ignoring the (un)making of place that constituted the conditions for what a desirable or beautiful 'natural world' meant - a concept that frames 'world' as picture, over and against worldhood as being-in-the-world (Heidegger 1977) - such a history legitimates the violence that was inherent to settler conceptions of natural beauty, as well as the ongoing (un)making that such concepts continue to produce. This legitimation effect functions with a logic similar to that of the naming ceremony. The significance of place has been decontextualised from Ngambri worldhood, mediated through the mechanisms of Western place-(un)making, and deployed as a means to consecrate settler dominance.

10 A similar point is made by Deborah Bird Rose: 'The right hand of conquest can be conceptualised as beneficent in its claims: productivity, growth, and civilisation are announced as beneficial actions in places where these purportedly had not existed before. The left hand, by contrast, has the task of erasing specific life. Indigenous peoples, their cultures, their practices of time, their sources of power, and their systems of ecological knowledge and responsibility will all be wiped out, and most of the erasure will be literal, not metaphorical. The left hand creates the tabula rasa upon which the right hand will inscribe its civilisation.' (Rose 2004: 62)

11 These particular practices of making oneself secure through place-(un)making are relative to the perspective of settlers, as they equally imply the displacement and terrorisation of Indigenous people. These early acts of enclosure can also be read as part of a genealogy of settler Australia's own displacement anxiety (Curthoys 1999). As a final thread in the multivalent theme of 'security', these practices of home-(un)making can be read in defutural terms, as the cultures of ecological destruction they founded delimit the future of settler culture itself (Fry 2007). 
A further characteristic of the 'response to place' discourse is that it appears to wilfully misrecognise how the dominant(ing) logic of the Griffins' plan was one in which the 'natural' was made explicitly subordinate to the unfolding sway of modernity:

The hills, where practicable ... are utilized as the elevated foundations for the utilitarian buildings of dominating importance. ... Elsewhere in the lesser remaining instances, hills are in general avoided by the geometrical avenues and streets and allowed to crop through only in places where they least interfere with the traffic and can be utilised for informal recreation or large residence sites, sanitoria, Hotels, etc. (Griffin 1912: 9-10, my emphasis)

The claim that the Griffins' plan 'is a response to the particular place it is in', is further troubled by an incoherent conception of 'place'. Certainly the Griffins' plan took into account various geographical features of the site, but this could only occur on the basis that 'the place' had already been constructed as a capital city site, through the work of surveying, mapping, modelling and painting. The Griffins' designing, therefore, was in no way a response to a 'particular place' to which they could have had any 'direct' access. Their designing was based on a sense of place that had been deliberately designed and crafted by the settler-colonial administration. The fact that they produced their submission on a different continent is one thing. ${ }^{12}$ The much more substantial point, however, is that, regardless of any empirical 'where', the worldhood of the Griffins, the mode of dwelling that they shared with their white, antipodal peers, meant that they could only ever have produced a Western interpretation of a mediated representation, of a place that had been culturally (un)made into a site of settler occupation since at least the 1820s. Against the rhetoric of 'imperial history', ${ }^{13}$ the achievements of the Griffins can be seen, therefore, as a contribution to the ontological designing of the same matrix of colonial power that continues to threaten the worldhood of Indigenous people today.

12 While Griffin would eventually adapt his designs to what he saw 'on the ground', he would never see 'it', the place, 'as such'. His vision would always mediated by a cultural imaginary, particularly as it was ontologically shaped by how the space had already been represented and imagined. For instance, the following description speaks to the gap that existed between Griffin's idealised spatial imaginary and a referent whose ontology always exceeded its various representations: 'Although impressed with the beauty of the capital's site, [Griffin] found the future city's precincts were not pristine. In fact, as he discovered on his first Australian visit, the valley had been extensively grazed, the river banks eroded and the once forested slopes now largely denuded.' (Vernon 2002: 21)

13 For more on what is meant by imperial history see note 1. 


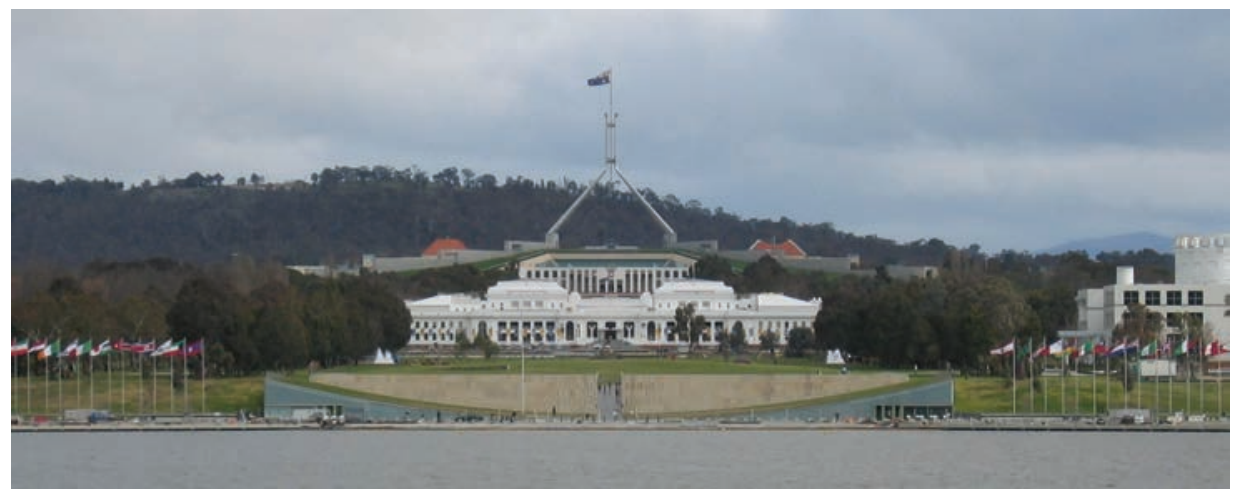

Figure 4. Canberra, 2005, showing Lake Burley Griffin (foreground), Old Parliament House (middleground), and Parliament House (background).

Source: http://en.wikipedia.org/wiki/File:Lake-ParlHouse.JPG, accessed 4 Oct. 2012. Photography: Adz

\section{Conclusion: (Un)making (de)colonial futures}

In 1834, a Polish naturalist prematurely declared that the 'natives' of the Ngambri country were 'now no more!' (Jackson-Nakano 2001: 49). Like the case of Nellie Hamilton's death, this claim was one of many instances in which an author would attempt to erase the existence of the Ngambri. This effect continues in writing about the design of Canberra, albeit in more subtle ways. In his account of Canberra's planning history, for instance, Christopher Vernon describes the transformation of the site from an 'obscure inland plateau' to Australia's 'greatest achievement in landscape architecture and town planning' (Vernon 2006: 130). While obviously ethnocentric (the land was and remains significant to the Ngambri), the coding of this description conveys more than was intended. 'Obscure' derives from the Latin obscurus, denoting 'hidden', 'secret' and 'dark'. The implication is that Canberra was singularly unveiled as a place by the intervention of Western modernity; it was through the disciplines of craft, planning, engineering and architecture that the region was imbued with (colonial) significance. That the mythical home of settler sovereignty in Australia would be depicted as having emerged from place of darkness is both ironical and hypocritical. As Mignolo, has observed, designating places of 'darkness' is 'part of the rhetoric of modernity (geographical racism) hiding the logic of coloniality' (Mignolo 2011: xx).

What I have tried to show here is that this kind of discursive erasure is an expression of the elimination logic that animates the socio-material designing of the city. I am attempting to counter this effect by writing a history that recalls what has been unmade by settler-colonial making. In doing so I demonstrate how representing the artefacts of settler-colonial designing as benign objects of beauty, progress, or otherwise, obscures the degree to which the ontological designing of settler-colonialism is both defutural and ethnocidal. 
This is a reading of settler-colonialism as designing force that includes craft as part of its material culture. While my focus has been the period from 1820 to 1913, I argue that this history depicts an effect that persists into our contemporary condition (see also Pieris 2012). While Australia now celebrates its 'multiculturalism', this liberal ideology continues to frame the settler state as a neutral mediator amongst equivalent claims to identity, even as it continues to exercise the power to condition relations between people and land. In doing so, it continues to encourage capitalistic, colonial, and unsustainable modes of dwelling.

\begin{abstract}
Matthew Norman Kiem is an independent researcher currently teaching in courses on design history at UTS: Insearch, Sydney, Australia. His work focuses on issues related to design for sustainable futures and the Urmadic University project. matthewkiem.net
\end{abstract}

\title{
Acknowledgements
}

I would like to thank those who have assisted me in various ways with researching and writing this paper. I am particularly indebted to Tara Andrews, Louise Crabtree, Tim Frewer, Abby Lopes, and Wenny Theresia. While I take responsibility for the remaining shortcomings, the comments and recommendations of my two anonymous reviewers have also been invaluable.

\section{References}

Agamben, G. 1998, Homo Sacer, Stanford University Press.

Agamben, G. 2001, 'On security and terror', Frankfurter Allgemeine Zeitung, vol. 20, Sept., viewed 25 Mar. 2013, http://www.egs.edu/faculty/giorgioagamben/articles/on-security-and-terror/

Anderson, B. 1991, Imagined Communities: Reflections on the origin and spread of nationalism, New York: Verso.

Australian Bureau of Statistics, 2010, Indigenous Statistics for Students, viewed 29 Oct. 2012, http://www.abs.gov.au/websitedbs/CaSHome.nsf/4a2563530 01af3ed4b2562bb00121564/68f064d21b22553aca25758b0011827f!OpenD ocument

Australian Bureau of Statistics, 2012, Aboriginal and Torres Strait Islander Prisoner Characteristics, viewed 29 Oct. 2012, http://www.abs.gov.au/ ausstats/abs@.nsf/Products/875C813AF74635EBCA25795F000DB4EF?op endocument

Banivanua-Mar, T. \& Edmonds, P. (eds) 2010, Making Settler Colonial Space: Perspectives on race, place and identity, Basingstoke: Palgrave Macmillan. 
Bateman, F. \& Pilkington, L. (eds) 2011, Studies in Settler Colonialism: Politics, identity and culture, Basingstoke: Palgrave Macmillan,

Bayet-Charlton, F. 2003, 'Overturning the doctrine: Indigenous peoples and wilderness - being Aboriginal in the environmental movement', in $M$. Grossman (ed.), Blacklines: Contemporary critical writing by Indigenous Australians, Carlton: Melbourne University Press.

Birch, T. 2003, "NNothing has changed": The making and unmaking of Koori culture', in M. Grossman (ed.), Blacklines: Contemporary Critical Writing by Indigenous Australians, Carlton: Melbourne University Press.

Brock, J.F. 2006, 'A tale of two maps - NSW in the 1830's by Mitchell and Dixon: Perfection, probity and piracy!', paper presented to the 400 Years of Mapping Australia: Darwin Conference - 23 to 25 August, viewed 5 Oct. 2012, http://www.xnatmap.org/adnm/docs/c06/aPaper\%2005.pdf

Carter, P. 2010, The Road to Botany Bay: An exploration of landscape and history, University of Minnesota Press.

Clastres, P. 1988, 'On ethnocide', Art \& Text, vol. 28, pp. 51-58.

Curthoys, A. 1999, 'Expulsion, exodus, and exile in white Australian historical mythology', in R. Nile \& M. Williams (eds), Imaginary Homelands: The dubious cartographies of Australian identity, Brisbane: University of Queensland Press.

Davison, G. 1993, The Unforgiving Minute: How Australians learned to tell the time, Oxford University Press.

Day, D. 1998, Conquest: How societies overwhelm others, Oxford University Press.

de Benoist, A. 1999, 'What is sovereignty?', Telos, vol. 116, pp. 99-118.

Department of Home Affairs, 1911, Information, Conditions and Particulars for Guidance in the Preparation of Competitive Designs for the Federal Capital City of the Commonwealth of Australia, viewed 5 Oct. 2012, http://nla.gov. au/nla.map-rm3095-1

Department of Home Affairs, 1913, The Federal Capital: Report explanatory of the preliminary general plan, viewed 5 Oct. 2012, http://nla.gov.au/nla.maprm3095-1

Duggan, L. 2009, “'A sort of mythical thing”: Canberra as an imaginary capital', Journal of Australian Studies, vol. 22, no. 57, pp. 83-92.

Foucault, M. 1980, 'Truth and power', Power-knowledge: Selected interviews and other writings, 1972-1977, Brighton: Harvester Press, pp. 109-33. 
Foucault, M. 1991, Discipline and Punish: The birth of the prison, trans. A. Sheridan, New York: Penguin Books.

Foucault, M. 2003, Society Must Be Defended: Lectures at the Collége De France, 1975-6, New York: Picador.

Foucault, M. 2007, Security, Territory, Population: Lectures at the Collége De France, 1977-8, New York: Palgrave Macmillan.

Foucault, M. 2008, The History of Sexuality Volume I, trans. R. Hurley, New York: Penguin Books.

Fry, T. 1994, 'Green hands against dead knowledge', Remakings: Ecology, design, philosophy, Sydney: Envirobook, pp. 87-102.

- - 1999, A New Design Philosophy: An introduction to defuturing, Sydney: University of New South Wales Press.

- - 2004, 'The sustainment and its dialectic', in A.-M. Willis (ed.), Design Philosophy Papers Collection One, Ravensbourne, Qld.: Team D/E/S, pp. 33-45.

- - 2007, 'Homelessness - A philosophical architecture', in A.-M. Willis (ed.), Design Philosophy Papers Collection Three, Ravensbourne, Qld: Team D/E/S, pp. 19-28.

- - 2009, Design Futuring: Sustainability, ethics and new practice, Sydney: UNSW Press.

- - 2011, Design as Politics, London; New York: Berg.

- - 2012, Becoming Human by Design, London; New York: Berg.

Gale, J. 1977, Canberra: History and legends, North Sydney: Library of Australian History.

Gammage, B. 2011, The Biggest Estate on Earth: How Aborigines made Australia, Crows Nest: Allen \& Unwin.

Graham, M. 1999, 'Some thoughts about the philosophical underpinnings of Aboriginal worldviews', Worldviews: Environment, Culture, Religion, vol. 3, pp. 105-18.

Greenhalgh, P. 1997, 'The history of craft', in P. Dormer (ed.), The Culture of Craft: Status and future, Manchester University Press.

Griffin, W.B. 1912, Federal Capital Design No 29 by WB Griffin - Original report, viewed 5 Oct. 2012, http://recordsearch.naa.gov.au

Heidegger, M. 1962, Being and Time, trans. J. Macquarrie \& E. Robinson, Oxford: Blackwell Publishing. 
Heidegger, M. 1977, 'The age of the world picture', The Question Concerning Technology and Other Essays, New York: Harper Torchbooks, pp. 115-54.

Heidegger, M. 2008, 'Building dwelling thinking', Basic Writings, New York: Harper Perennial Modern Thought, pp. 343-63.

Jackson-Nakano, A. 2001, The Kamberri: A history from the records of Aboriginal families in the Canberra-Queanbeyan district and surrounds 1820-1927 and historical overview 1928-2001, Canberra: Aboriginal History.

Lea, T. 2012, 'When looking for anarchy, look to the state: Fantasies of regulation in forcing disorder within the Australian Indigenous estate', Critique of Anthropology, vol. 32, no. 2, pp. 109-24.

McGaw, J., Pieris, A. \& Potter, E. 2011, 'Indigenous place-making in the city: Dispossessions, occupations and implications for cultural architecture', Architectural Theory Review, vol. 16, no. 3, pp. 296-311.

Mignolo, W.D. 2011, The Darker Side of Western Modernity: Global futures, decolonial options, Durham: Duke University Press.

Moreton-Robinson, A. (ed.) 2007, Sovereign Subjects: Indigenous sovereignty matters, Crows Nest: Allen \& Unwin.

Morgensen, S. 2011, 'The biopolitics of settler colonialism: Right here, right now', Settler Colonial Studies, vol. 1, no. 1, pp. 52-76.

Morrissey, P. 1995, 'Lines in the sand', Artlink, vol. 17, no. 3, pp. 20-3.

Pieris, A. 2009, Hidden Hands and Divided Landscapes: A penal history of Singapore's plural society, Honolulu: University of Hawaii Press.

- - 2012, 'Occupying the centre: Indigenous presence in the Australian capital city', Postcolonial Studies, vol. 15, no. 12, pp. 221-48.

Reid, P. 2002, Canberra Following Griffin: A design history of Australia's national city, Canberra: National Archives.

Rose, D.B. 2004, Reports From A Wild Country: Ethics for decolonisation, Sydney: University of New South Wales Press.

Smith, L.T. 1999, Decolonizing Methodologies: Research and indigenous peoples, New York: Zed Books.

Stoler, A.L. 2008, 'Imperial debris: Reflections on ruins and ruination', Cultural Anthropology, vol. 23, no. 2, pp. 191-219.

- - 2011, 'Colony', Political Concepts: A Critical Lexicon, no. 1, http://www. politicalconcepts.org/issue1/colony/ 
Veracini, L. 2010, Settler Colonialism: A theoretical overview, Basingstoke: Palgrave Macmillan.

- - 2012, 'Suburbia, settler colonialism and the world turned inside out', Housing, Theory and Society, vol. 29, no. 4, pp. 339-57.

Vernon, C. 2002, A Vision Splendid: How the Griffins imagined Australia's capital, Canberra: National Archives of Australia.

Vernon, C. 2006, 'Canberra: Where landscape is pre-eminent', in D. Gordon (ed.), Planning Twentieth Century Capital Cities, New York: Routledge, pp. $130-49$.

Willis, A.-M. 2007, 'Ontological designing - laying the ground', in A.-M. Willis (ed.), Design Philosophy Papers: Collection Three, Team D/E/S, Ravensbourne, pp. 80-98.

Willis, A.-M. 2012, 'Ontological Designing and Mapping', Design Philosophy Papers, no. 2.

Winograd, T. \& Flores, F. 1987, Understanding Computers and Cognition: A new foundation for design, Sydney: Addison-Wesley.

Wolfe, P. 1992, 'Reluctant invaders', Meanjin, vol. 51, no. 2, pp. 333-38

- - 1997, 'Should the subaltern dream? "Australian Aborigines" and the problem of ethnographic ventriloquism', in S.C. Humphreys (ed.), Cultures of Scholarship, Ann Arbor: University of Michigan Press.

- - 2006, 'Settler colonialism and the elimination of the native', Journal of Genocide Research, vol. 8, no. 4, pp. 387-409. 